\title{
AN AUTOMATED MODULE OF SELF-DEFENCE AND MASKING OF NAVAL VESSELS OF THE POLISH NAVY WITH THE USE OF MINIATURE ROCKET MISSILES CALIBER 70 AND 40 MM
}

\section{Paweł Dobrzyński*, Stanisław Lipski**, Bogdan Machowski*, Rafał Miętkiewicz ${ }^{* * *}$, Tomasz Olszewski****}

* Military University of Technology, Faculty of Mechatronics and Aviation, gen. W. Urbanowicza 2 Str., 00-908 Warsaw, Poland; e-mail: \{pawel.dobrzynski; bogdan.machowski\}@wat.edu.pl

** Institute of Precision Mechanics, Duchnicka 3 Str., 01-796 Warsaw, Poland; e-mail: stlipski@gmail.com

*** Polish Naval Academy, Faculty of Command and Naval Operations, Śmidowicza 69 Str., 81-127 Gdynia, Poland; e-mail: r.mietkiewicz@amw.gdynia.pl

${ }^{* * * *}$ Polska Grupa Zbrojeniowa S.A., Nowy Świat 4a Str., 00-497 Warsaw, Poland; e-mail: tomasz. olszewski@pgzsa.pl

\begin{abstract}
This article is an attempt to interest the subjects associated with maritime technology - in the possibilities of increasing the safety of Polish Navy ships (or civilian ships), which may be threatened by attacks of maneuvering missiles and drones moving at low altitude at high speed. The concept proposed by the team was initially verified in simulation tests and the obtained results of these studies indicate that the automated missile self-defence system based on guided and unguided missiles with caliber $40 \mathrm{~mm}$ and $70 \mathrm{~mm}$, can be an effective means of self-defence (even the smallest vessels). Small dimensions and mass as well as simplicity of use and reliability of this weapon system allow to believe that $40 \mathrm{~mm} \mathrm{MLRS}^{1}$ could also be used by special forces of Polish Navy in offensive operations (destruction of lightly armoured objects of surface or ground, vehicles,
\end{abstract}

1 Multi Launch Rocket System. 
force, putting smoke screens, mine mines) to $2000 \mathrm{~m}$. For that reason, the system is referred to by the team of implementers as 'pocket rocket artillery'.

\section{Key words:}

marine combat systems, safety and protection of shipping, armaments and specialized equipment, port and critical infrastructure protection, utilities and specialized equipment, rocket systems of self-defence and ship's masking, testing and certification of products in the field of defence and security of the Republic of Poland.

Research article

(c) 2018 Paweł Dobrzyński, Stanisław Lipski, Bogdan Machowski, Rafał Miętkiewicz, Tomasz Olszewski This is an open access article licensed under the Creative Commons Attribution-NonCommercial-NoDerivatives 4.0 license (http://creativecommons.org/licenses/by-nc-nd/4.0/) 


\section{INTRODUCTION}

The system of political and military forces in the Baltic Sea basin and the course of the latest conflicts on the international arena indicate that the main means of combating Polish Navy vessels may be Anti-Ship Maneuvering Missiles (ASMM). The ability to launch ASMM from platforms: air, surface, underwater or land causes that these types of missiles are the basic weapon for fighting surface units. A characteristic feature of ASMM is that they enable effective attacking of ships without affecting the fire reaction of the directly attacked sea unit or convoy.

According to the authors of this study there are no intensive works in Poland, the results of which would allow to increase the missile defence capabilities of Polish Navy vessels, e.g. through the innovative use of the latest technology and technological achievements. It is a common knowledge to all those interested parties of the enormous costs borne by the public to acquire and operate NAVY ships. The proposal of combating ASMM with anti-aircraft systems such as Grom/Piorun should not be seriously considered. This is due to the fact that in the absence of accurate knowledge of time and the expected direction of attack by ASMM, the time needed in such sets to move from the standby position to the combat position lasts at least a few seconds (in each of them the ASMM approaches a few hundred meters). The construction of self-guided warheads and the method of cooling Grom/Piorun missiles causes that it is not effective (not recommended in practice) to shoot objects below $10 \mathrm{~m}$. It is also impossible to shoot with a series of projectiles to increase the probability of ASMM destruction.

\section{MEANS OF ATTACK OF SHIPS NAVY POSSIBLE TO BE USED BY A POTENTIAL ENEMY}

The development of autonomous and mobile systems as well as the progressive miniaturization of combat means allow the opponent to use tactics that have hitherto been encountered sporadically or not at all. The principle propagated by tactics of many Navy 'fight the archer - not arrows', lost its significance in a world in which the ignition of anti-ship's means takes place far beyond the reach of the ship's means of detection. Examples of such threats are presented in tab. 1. ASMM's seem particularly dangerous because of their small radiolocation signature, low flight altitude and the huge distance of discharge launch reaching hundreds and in the future, thousands of kilometres.

$3(214) 2018$ 
ASMMs are powered by turbojet engines along the entire length of the aerodynamic flight and usually carry one warhead (penetration, demolition, cumulative, atomic). Examples of such missiles are: American 'Harpoon'/'Slam', Swedish short-range ASMM RBS-15 or Russian 'Zon Ch-35 Uran'. The ranges of these missiles vary, depending on the version, from 100 to $300 \mathrm{~km}$. They can therefore be fired far beyond the range of the warning systems owned by Polish Navy.

The characteristic feature of ASMM is that they move at a speed of about $1000 \mathrm{~km} / \mathrm{h}$ - which results from the physics of phenomena occurring in propulsion engines of ASMM jet engines as well as their optimization, enabling, among others. reducing the thermal/radiolocation signature or increasing the range of such a projectile. The inertial missile navigation system and built-in digital terrain maps allow ASMM s to maneuvre to reduce the likelihood of detection and destruction. Missiles of this type are moving at altitudes from a few to a dozen meters above sea level, by which they delay their detection by optical and radar methods. In the last phase of the ASMM flight, they are guided by the indications of on-board radars or infrared detectors. The intelligence of the modern ASMM control system allows you to perform intentional tactical maneuvers (e.g. directing a projectile so that the final phase of the flight towards the attacked ship or ship is carried out from the sun's side).

Tab. 1. Examples of Navy ships' threats in the classical and hybrid conflict

\begin{tabular}{|c|c|c|c|c|}
\hline Type of ship's threat & Type of trajectory & $\begin{array}{c}\text { Dump distance } \\
{[\mathrm{km}]}\end{array}$ & $\begin{array}{l}\text { Flight speed } \\
{[\mathrm{m} / \mathrm{s}]}\end{array}$ & $\begin{array}{c}\text { Cross-section } \\
{\left[\mathrm{m}^{2}\right]}\end{array}$ \\
\hline ARM ('Search Radar') & $\begin{array}{c}\text { diving straight } \\
\text { ahead } \\
60^{\circ} . .20^{\circ} \\
\end{array}$ & $>10$ & $300 \ldots 700$ & $0.05 \ldots 0,1$ \\
\hline $\begin{array}{l}\text { Against the ship } \\
\text { maneuvering missiles }\end{array}$ & $\begin{array}{l}\text { ceiling low straight } \\
\text { or diving }\end{array}$ & $>100$ & $250 \ldots 500$ & $0.5 . .0,1$ \\
\hline 'Stand Off'/'Smart Bomb' & $\begin{array}{c}\text { free } \\
\text { or directed }\end{array}$ & $2 . .10$ & $250 \ldots 350$ & 0.1 \\
\hline 'Kamikaze Dron' & $\begin{array}{c}\text { low } \\
\text { or diving ceiling }\end{array}$ & $>20$ & $100 \ldots 200$ & $0.1 . .1$ \\
\hline
\end{tabular}




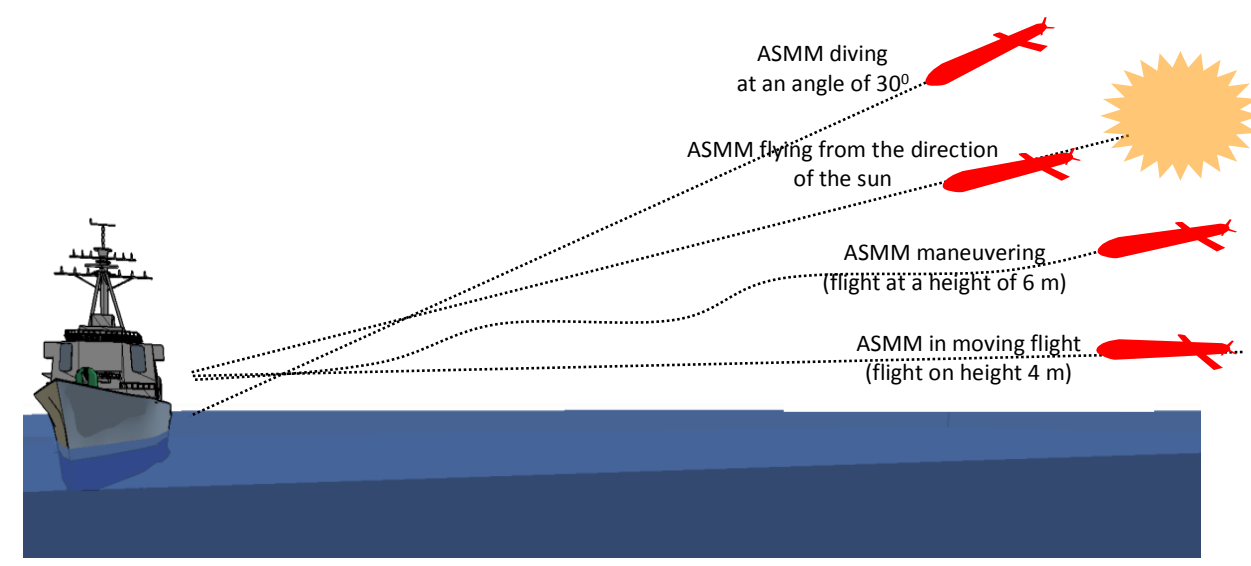

Fig. 1. Examples of ASMM trajectories

\section{ANALYSIS OF THE MISSILE DEFENCE EFFECTIVENESS OF THE SHIP}

The effectiveness of anti-missile defence depends on many technical and tactical aspects, which include:

- automatic operation;

- resistance to intensive operation of active and passive disturbances;

- short reaction time;

- the ability to fight multiple anti-ship missiles at the same time or the minimum time to change targets;

- high probability of destroying the target with one counter-rocket;

- simplicity of construction and service as well as resistance to atmospheric factors (atmospheric discharges, humidity, salt, etc.);

- minimum number of staff and the ability to be served by ad hoc trained people.

Since the perceptive abilities of ship crews are limited - it is assumed that under conditions of a real Navy naval attack by ASMM, the main burden of fire tasks should be shifted from combating carriers to combating warfare agents. Combating hazards by manual or semi-automatic artillery systems - in the case of Polish Navy units it seems impossible due to failure to meet the condition of the effectiveness of the ship's shield system:

where:

$$
t_{\text {RES }} \leq t_{F L Y}
$$

- $t_{R E S}[\mathrm{~s}]$ - response time of the anti-missile system:

$$
t_{R E S}=t_{D E T}+t_{G O}+t_{T S P}+t_{S L O}+t_{W E A}+t_{S H O O T}+t_{O B S} ;
$$


- $t_{D E T}[\mathrm{~s}] \quad$ - the time needed to detect ASMM;

- $t_{G O}[\mathrm{~s}] \quad$ - time to give orders;

- $t_{T S P}[\mathrm{~s}]$ - time to take a shooting position;

- $t_{S L O}[\mathrm{~s}] \quad$ - time to start launcher and projectile;

- $t_{W E A}[\mathrm{~s}]$ - time to aim the weapon;

- $t_{\text {Sноот }}[\mathrm{s}]$ - shooting time:

$$
t_{\text {SHOOT }}=t_{\text {START }}+\frac{d_{\text {SAFE }}}{V_{\text {MISS }}} ;
$$

- $t_{\text {START }}[\mathrm{s}] \quad$ - time of launching a missile;

- $V_{\text {MISS }}[\mathrm{m} / \mathrm{s}]$ - average speed of missile flight on the road $d_{S A F E}$;

- $d_{S A F E}[\mathrm{~m}]$ - distance in which the initiation of the ASMM warhead will not cause losses on the ship;

- $t_{O B S}[\mathrm{~s}] \quad$ - time of observation of the results of the conducted fire;

- $t_{F L Y}[\mathrm{~s}] \quad-$ ASMM flight time (from the time it was detected by the crew until the target was reached):

$$
t_{F L Y}=\frac{d_{D E T}}{V_{A S M M}} ;
$$

- $V_{A S M M}[\mathrm{~m} / \mathrm{s}]$ - average ASMM flight speed on the section $d_{W Y K R} ;$

- $d_{D E T}[\mathrm{~m}] \quad$ - detection's distance of ASMM.

A separate commentary requires time $t_{D E T}$, i.e. the time needed to detect the ASMM, which for the purposes of the article has been determined taking into account the following assumptions:

- the radar station of the ship is unable to detect ASMM due to its low signature;

- detection of ASMM occurs by using visual observation means such as binoculars or a thermal imaging camera ${ }^{2}$;

- the state of the sea is 0 ;

- no precipitation or mist.

From the above assumptions, it follows that $d_{D E T}$, ie the distance of the detection of ASMM by the ship's crew, will depend only on the curvature of the earth and the following parameters:

- $h_{O B S}[\mathrm{~m}]$ - the height of the observer's position (10 $\mathrm{m}$ are considered for further consideration);

2 For manyyears, the authors have been unsuccessfully recommending the deployment of miniature infrared alerters to Polish Navy ships as effective systems for detecting objects around the ship. 
- $h_{A S M M}[\mathrm{~m}]$ - flight height ASMM n.p.m. (5 m were taken for further consideration).

The fig. 2 shows the phenomenon of hiding objects below the so-called the visual horizon, the distance of which for $h_{O B S}<<r_{E A R T H}$ can be calculated using a simplified formula:

$$
d_{H W Z O} \approx 3569 * \sqrt{h_{O B S}}=3569 * \sqrt{10}=11286 m .
$$

Since it was assumed that ASMM are moving at the level of hASMM, for the assumed assumptions, the total distance of detection $d_{D E T}$ can be calculated on the basis of:

$$
d_{D E T} \approx d_{H W Z O}+d_{H W Z P}=11286+3569 * \sqrt{5}=19266 m
$$

\section{0}

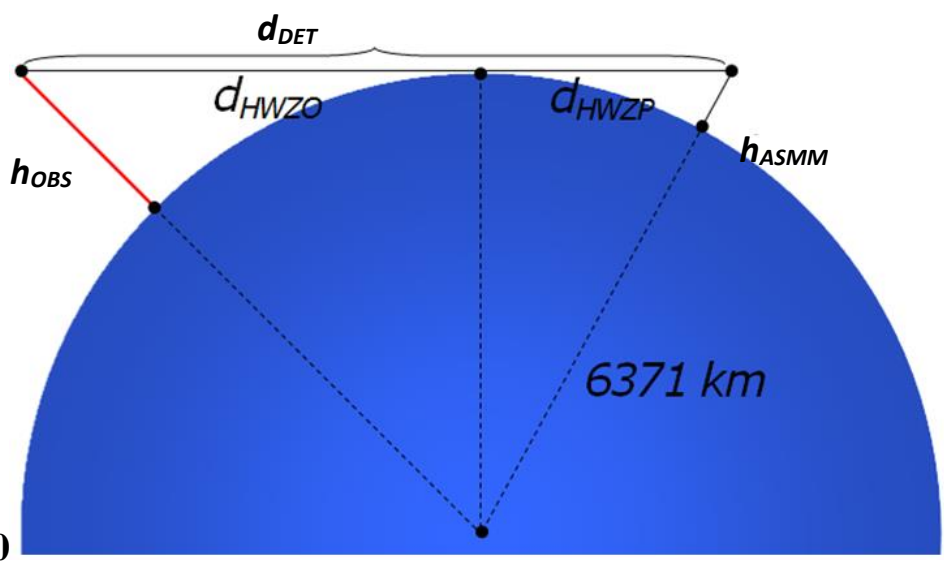

Fig. 2. Illustration of the lack of the possibility of observing objects behind the visual horizon

Observation distance theoretically allows the crew to detect PMM at a distance of $19 \mathrm{~km}$, which, with not the highest speed VASMM = $278 \mathrm{~m} / \mathrm{s}$, means that a flying projectile in a straight line will reach the ship within:

$$
t_{F L Y} \approx \frac{d_{D E T}}{V_{A S M M}}=\frac{19266 \mathrm{~m}}{278 \mathrm{~m} / \mathrm{s}}=69.3 \mathrm{~s} .
$$

This value seems to be sufficient for the early detection of the object and the preparation of the missile shield of the ship. It should be remembered, however, that the real times of $t_{R E A K}$ will be much smaller — this is due to many conditions:

- limiting the range of visibility that may be caused by:

- absorption of the luminous flux in the visible/infrared spectrum due to molecular absorption, extremely uneven - depending on the frequency, 
- diffusion of luminous flux - the atmosphere is a mechanical mixture consisting of gases, vapors, liquid droplets and solid particles,

- turbulence, i.e. time-space changes of the layered refractive index, caused by displacement of air layers or fluctuations in its temperature and density;

- the need to observe the entire space around the ship, through a limited number of observers, who may additionally be tired or sleepy;

- unwillingness of observers to trigger false alarms - thus the need for longer observation of the object or a request to confirm the detection of the object by another observer;

- limited resources for night observation - saturation of Navy RP vessels with thermal imaging cameras or image intensifiers is insufficient for simultaneous observation of all possible directions of danger;

- ASMMs may be obscured by obstacles limiting the field of observation in a given direction (smoke, fog, convoy ships, islands, sun).

Taking into account the above factors, it was assumed for further considerations that the average time needed to detect ASMM by the ship's crew $t_{D E T}=30 \mathrm{~s}$.

Another important parameter to be determined is the distance dBEZP, in which the initiation and explosion of the ASMM warhead will not cause losses on the ship. The forecast of the effects of the blast wave on people and objects requires information about the amount of overpressure produced by this wave at given distances from the place of explosion. The most important parameter of the pressure profile in the blast wave is overpressure on the front of the blast wave Ps [kPa].

Tab. 2. Effects of blast wave overpressure on humans

\begin{tabular}{|l|c|}
\hline \multicolumn{1}{|c|}{ The effects of action } & $\boldsymbol{P s}$ \\
\hline No injuries (safe pressure) & $<\mathbf{2 0 ~} \mathbf{~ P a}$ \\
\hline Slight injuries - short-term damage to the hearing organs, light bruises & $40 \mathrm{kPa}$ \\
\hline $\begin{array}{l}\text { Medium injuries - damage to the entire body, haemorrhage, fainting, } \\
\text { fractures and dislocation of the limbs }\end{array}$ & $50 \mathrm{kPa}$ \\
\hline $\begin{array}{l}\text { Severe injuries - serious damage to the entire body, brain and abdominal } \\
\text { damage, severe haemorrhage }\end{array}$ & $100 \mathrm{kPa}$ \\
\hline Very serious injuries - deaths & $>100 \mathrm{kPa}$ \\
\hline
\end{tabular}

The analysis of tab. 2 shows that if seafarers aboard an attacked ship are not to suffer any injuries caused by an explosion (fragments resulting from the destruction of the ASMM head are not taken into account) then the overpressure of 
the wave front should not be at a distance of $R[\mathrm{~m}]$ from the explosion site reach values greater than $20 \mathrm{kPa}$, hence:

$$
d_{S A F E} \geq R
$$

According to the Regulation of the Minister of Economy RP, the ability of a given explosive to generate a shockwave is determined comparing to the reference explosive (crystalline hexogen), using the hazard factor $R_{Z}$, which can be derived from the formula:

$$
R_{Z}=4.71 \cdot 10^{-4} \cdot \sqrt{Q \cdot V}
$$

where: $Q[\mathrm{~kJ} / \mathrm{kg}]$ - explosion heat of a given material;

$V\left[\mathrm{dm}^{3} / \mathrm{kg}\right] \quad-$ the specific volume of explosive products in normal conditions.

Determination of the hazard ratio $R_{z}$ allows you to determine the so-called hexogen equivalent $G$ :

$$
G=R_{Z} \cdot M
$$

where: $M[\mathrm{~kg}]$ - is a mass of explosive.

The overpressure of the shock wave $P_{s}$ as a function of the distance of the wave front $R$ from the place of explosion, taking into account the equivalent of the hexogen of the stored charge $G$, we can calculate using the formula:

$$
P_{S}=980 \cdot\left(R G^{-\frac{1}{3}}\right)^{-1.89}
$$

Assuming the exemplary parameters of the model ASMM warhead:

- mass of explosive head: $500 \mathrm{~kg}$;

- explosive material: TNT (explosion heat $Q=4560 \mathrm{~kJ} / \mathrm{kg}$;

- specific volume $V=825 \mathrm{dm}^{3} / \mathrm{kg}$ ),

we calculate the overpressure of the shockwave $P_{s}$ as a function of the distance $R$, which is illustrated in the graph in fig. 3.

The chart indicates the distance which, according to the adopted criterion, means safe distance for the crew of the ship staying on board during the explosion of the warhead caused by the missile system. The character of the graph of shock wave overpressure changes shows that its value exponentially decreases, which 
suggests that for the ship's shield system the safe distance will be smaller than the distance of the anti-missile weapons. Therefore, for further analyses adopted:

$$
d_{S A F E}=d_{M I N},
$$

where: $d_{M I N}[\mathrm{~m}]-$ minimum distance of use of anti-missiles.

In the light of the above analyses, let's try to estimate the time of the ship's reaction, which crew is equipped with $72-\mathrm{mm} \mathrm{PZR}^{3}$ GROM and tries to counteract ASMM class 3M-54 'Calibr'. It is worth noting that the crew is forced to deliberately violate the provisions of PZR GROM shooting instructions - prohibiting shooting this set to objects lower than $10 \mathrm{~m}$ from the fire station level (this means that the shooter standing on the deck 10 meters above sea level should not fire for the purposes of lower than $20 \mathrm{~m}$ above sea level).

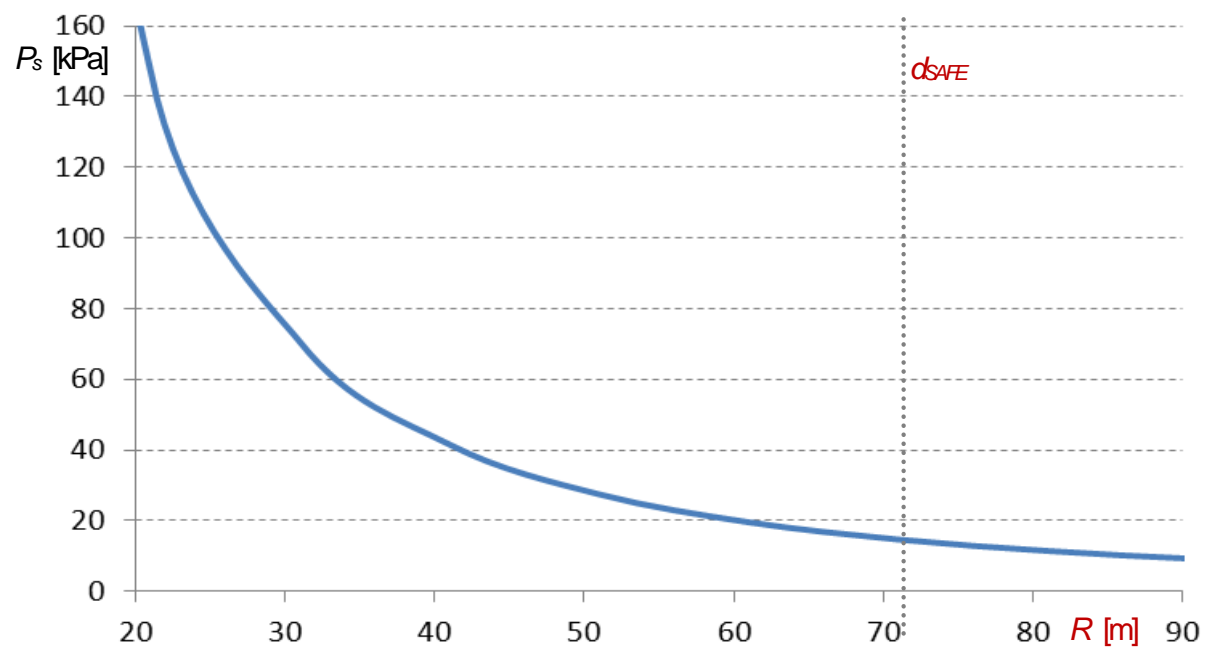

Fig. 3. Graph of shock wave overpressure change as a function of distance from the explosion site

We assume that PZR GROM is fastened on board the ship in a special holder, with an attached NBZ cartridge ${ }^{4}$ and is protected against moving by means of quick-detachable clamps. Therefore, the adopted times:

- time needed to detect ASMM by the crew $t_{D E T}=30 \mathrm{~s}$;

- time to give orders $t_{G O}=10 \mathrm{~s}$;

- time of taking the shooting position $t_{T S P}=10 \mathrm{~s}$;

${ }^{3}$ Anti-aircraft rocket kit.

${ }^{4}$ Cooling gas supply and dosing system detector. 
- time to start launcher and projectile $t_{S L O}=5 \mathrm{~s}$;

- time to aim the weapon $t_{W E A}=2 \mathrm{~s}$;

- time of launch of a missile missile $t_{S T A R T}=0.2 \mathrm{~s}$;

- minimum shooting distance MANPADS GROM $d_{M I N}=500 \mathrm{~m}$;

- average flight speed of the MANPADS GROM rocket missile on this road $V_{M I S S}=$ $650 \mathrm{~m} / \mathrm{s}$.

On the basis of the adopted data, reaction times were determined $t_{R E S}=30+10$ $+10+5+2+0.2+1.3=58.5 \mathrm{~s}$. At that time, the ASMM class 3M-54 'Calibr' according to the dependence on $t_{F L Y}$ will travel $17 \mathrm{~km}$. Assuming the most beneficial case, i.e. the one in which the detection time will be only 1 second - the minimum distance of detection of ASMM to fight it with PZR GROM is $10 \mathrm{~km}$. The detection of ASMM at a distance closer than $10 \mathrm{~km}$ significantly minimizes the effectiveness of the missile shield of the ship.

The analyses carried out lead to conclusions regarding the requirements for an effective missile defence system for Polish Navy vessels:

1. The system should operate in a maximum automated manner. The ship's commander's task may be to confirm the decision made by the system application software or to indicate the approximate direction on which the approaching ASMM or combat drone was noticed.

2. Anti-missiles missile systems of the ship's shell do not have to have large ranges, and hence, large dimensions and mass.

3. Elements of the system should be as miniaturized as possible and the low costs of purchase and operation of the system should enable their installation in a larger number on board each Polish Navy ship.

4. The anti-missile launchers should be equipped with non-cooled thermal imaging cameras enabling independent detection of ASMM or the interception of designated targets and automated fire guidance.

\section{SIMULATION OF THE SHIP'S ATTACK BY A SUBSONIC ANTI-SHIP MISSILE}

In order to confirm the conclusions from the previous chapter, the author team made a series of simulations of the attack on the ship Navy by a representative maneuvering missile. The following preliminary assumptions resulting from the experience of the authors and the literature analysis of the issue were adopted in the simulation so-called worst case:

- the ASMM takes the mowing flight at a height of $5 \mathrm{~m}$ above sea level. at an average speed of VASMM = $278 \mathrm{~m} / \mathrm{s}$ (about $1000 \mathrm{~km} / \mathrm{h}$ );

- ASMM performs maneuvers in a horizontal plane with overloads < 18 g;

3 (214) 2018 
- identification and decision to combat is made when the ASMM is located at a distance of $1500 \mathrm{~m}$ from the ship.

Fig. 4 presents examples of ASMM flight speed and path diagrams obtained from simulations. Waveform analysis shows that ASMM, wanting to make an effective hit to a ship, must reduce the value of its exchange rate parameter. This phenomenon is beneficial for the conversion of an apparent forward point and optoelectronic detection systems, because despite the significant overloads that affect ASMM (fig. 5), the angular velocities of this missile are relatively small and grow rapidly only when the ASMM is at a distance of $200 \mathrm{~m}$ to the defended ship (fig. 6).

In the presented simulation, it was assumed that the observation station (e.g. observation and tracking head) is located on the attacked ship and is fixed at a distance of $20 \mathrm{~m}$ from the point where the projectile hits the ship. For such assumptions, the results of the simulation show that until the ASMM has reached a distance of about $500 \mathrm{~m}$ from the ship, the angular velocities of tracking decreases, and the angle of the Target Sighting Line (TSL) is the largest. The angular velocities of the target tracking do not exceed $10 \mathrm{deg} . / \mathrm{s}(0.174 \mathrm{rad} / \mathrm{s})$, which corresponds to the rotational speed of the drives about $1.66 \mathrm{rpm}$. For the constructors of self-defence systems, the small required angular speed of tracking is important information, because this parameter determines the dimensions (dimensions), mass and power necessary for the propulsion of the launcher equipped with missile anti-missiles.

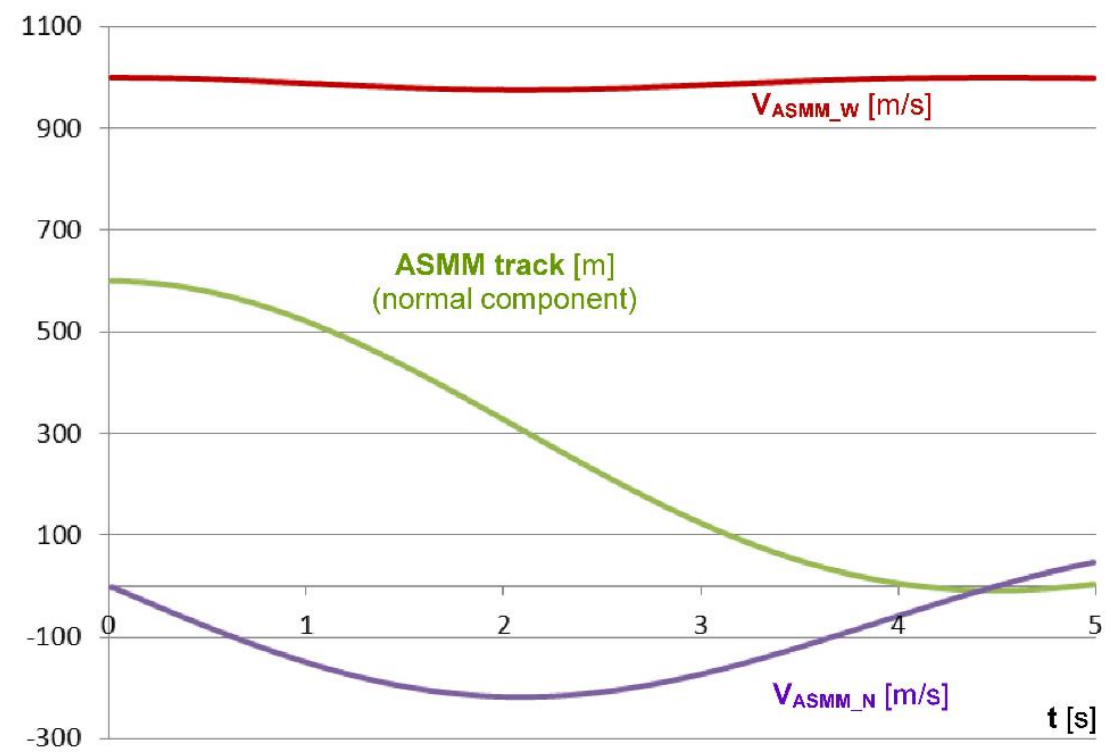

Fig. 4. Sample results of simulation of a subsonic ASMM attack - components of the velocity vector ASMM and flight path ASMM 


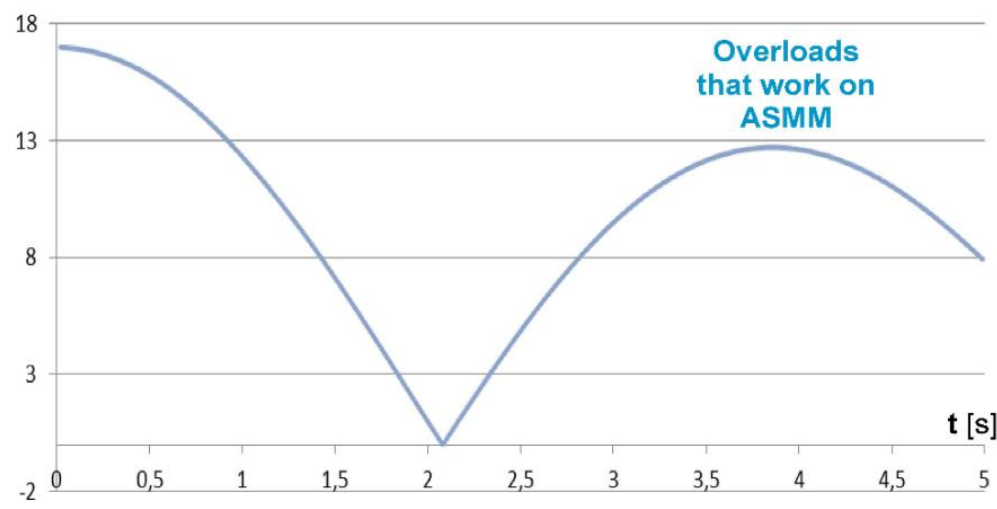

Fig. 5. Overloads operating on ASMM during a simulated attack

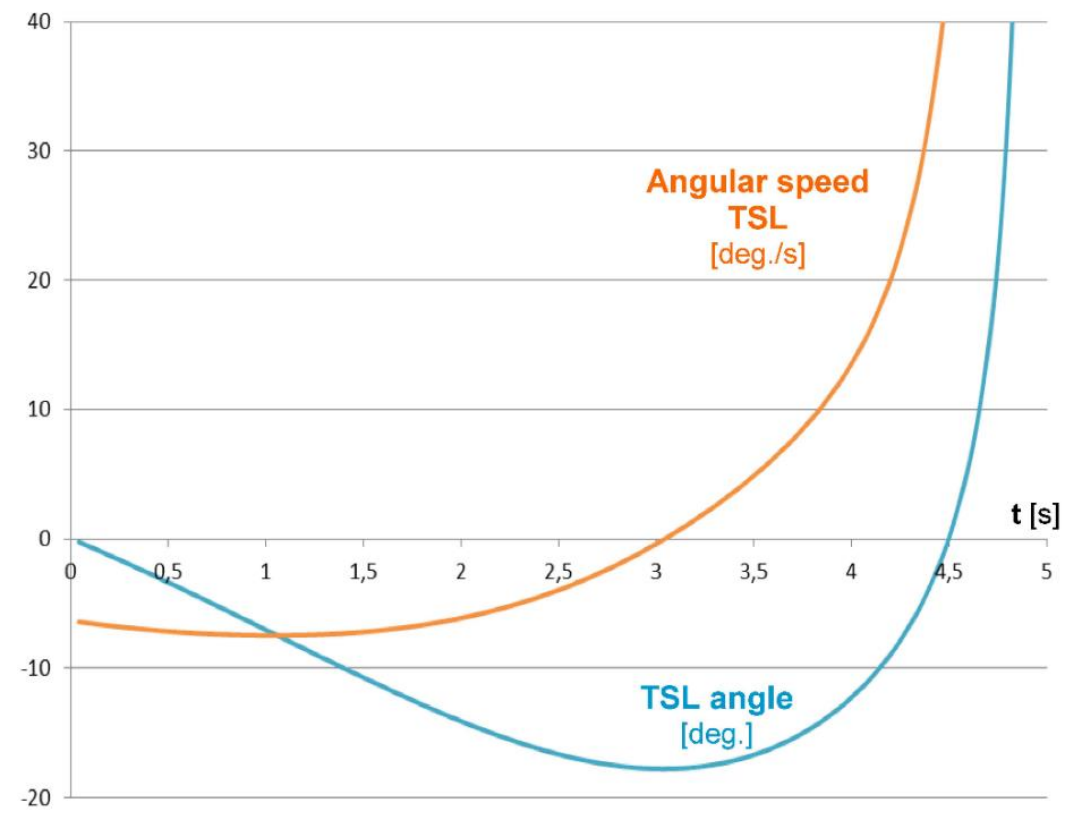

Fig. 6. Sample results of a simulated ASMM attack on a Navy vessel: TSL angle values over time, TSL angular speed

The conclusions that can be drawn on the basis of the simulations presented above confirm the conviction that combating ASMM seems to be easier task e.g. from combating an aircraft attacking a ship with the help of the gliding bombs - because in the latter case generally are unknown: speed, trajectory and manoeuvres of the bomb carrier. This is very important information for designers of ship missile self-defence systems, because it simplifies the necessary automation of the entire system. 


\section{AUTOMATED MISSILE SELF-DEFENCE AND SHIP MASKING SYSTEM}

The simulations and analyzes presented in the previous chapter convinced the authors of the article to propose a concept for the use of multi-conductor launchers of miniature projectiles, cal. $40 \mathrm{~mm}$, for the defence and masking of the ship. System assumptions:

- the system consists of at least 2 launch modules equipped with, among others in a box-shaped 23-pipe rocket launcher cal. $40 \mathrm{~mm}$ (fig. 7);

- no cooled infrared camera is attached to each platform - the basic module sensor;

- all fire modules, although completely autonomous, cooperate with each other (exchanging data using a fibre optic), among others to passively determine the current distance to the ship's attacking object;

- each module has its own microprocessor system, thanks to which it works in an automatic way - the task of the crew is only to indicate the direction of the threat and determine its character;

- the launcher has the ability to remember what type of projectile is in which tube guide;

- rocket missiles of various types can be placed in the launcher:

- for the destruction of winged rockets/drones/maneuvers missiles, small subversive boats, etc.,

- spreading radiolocation interference in the form of film strips,

- flares,

- smoke grenades, etc.;

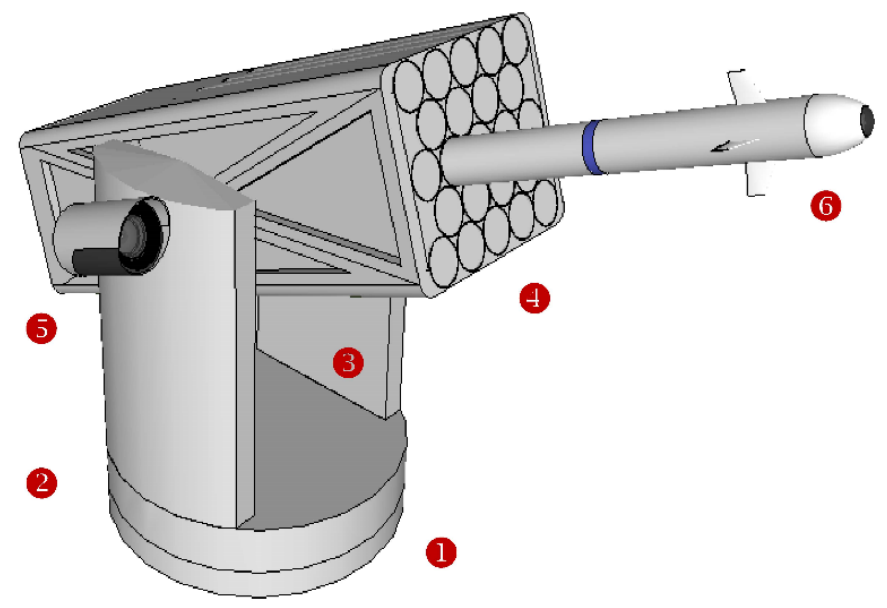

Fig. 7. Visualization of the $40 \mathrm{~mm}$ MLRS of the 'MORS' guards shell: (1) 15 "lower bed, (2) upper bed, (3) portal, (4) 23 tube launcher-container, (5) tracking camera, (6) missile 'MORS' 
- before firing in each projectile, the time and manner of operation of the warhead is programmed in such a way as to increase the area of the projectile and the entire salvo;

- it is possible to shoot simultaneously with detonating bullets as well as missiles disturbing the sensors of the ship's attacking objects.

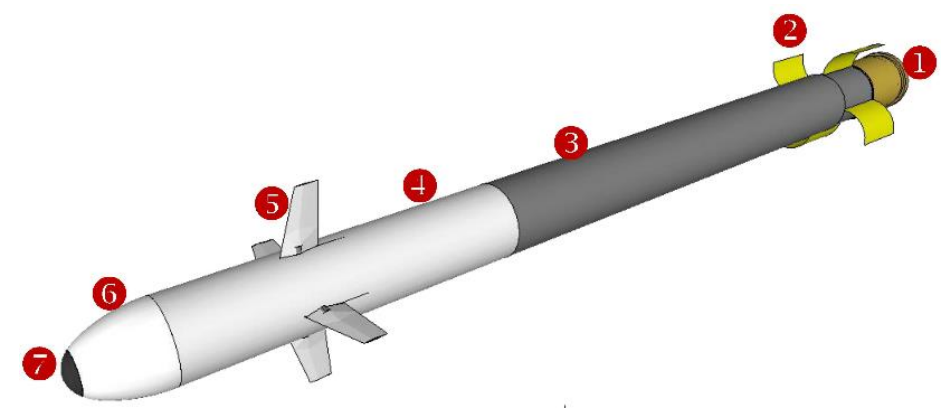

Fig. 8. Visualization of a $40 \mathrm{~mm}$ projectile shell of 'MORS' ships: (1) a bullet launching engine in the form of a $40 \times 53$ cartridge, (2) folding fins, (3) a motor part, (4) warhead, (5) analog gears,

(6) 'seeker IR', (7) germanium lens

Caliber

Bullet weight

Overloads are available

Length

Type of sensory head

The maximum angle of view of the head

The real angle of view of the detector

The ability to capture the target on the fly

Maximum speed of targets:

Time to shoot

The average speed of the flight on the marching section

The weight of the warhead

The maximum working time of the head

The method of launching the projectile

Type of rudders

Maximum range

Type of launcher

Estimated demand

\section{Pocket}

Rocket

Artillery Ballistic missile
"KORD"

$40 \mathrm{~mm}\left(1,57^{\prime \prime}\right)$

$2,6 \mathrm{~kg}$

$400 \mathrm{~mm}$

$-$

-

lack of possibility

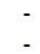

$150 \mathrm{~m} / \mathrm{s}$

$0,3 \mathrm{~kg}$

external propellant charge

-

anual / MLRS

20000 sp.
Self-guided missile

"PIKA

$40 \mathrm{~mm}\left(1,57^{\prime \prime}\right)$

$2,8 \mathrm{~kg}$

$6 \mathrm{~g}$

$400 \mathrm{~mm}$

uncooled

$10^{\circ}$ (fixed)

$10^{\circ}$

YES

$20 \mathrm{~m} / \mathrm{s}$

$<1 \mathrm{~s}$

$150 \mathrm{~m} / \mathrm{s}$

$0,3 \mathrm{~kg}$

battery life

external propellant charge analog $+/-10^{\circ}$

$1,2 \mathrm{~km}$

manual / drone / MLRS

$20000 \mathrm{sp}$.

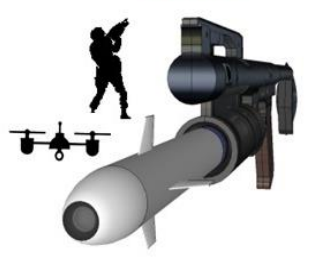

Anti-missile missile „MORS"

$$
\begin{gathered}
40 \mathrm{~mm}(1,57 ") \\
3,6 \mathrm{~kg} \\
6 \mathrm{~g} \\
\text { LR: } 600 \mathrm{~mm} \text { (ER: } 800 \mathrm{~mm} \text { ) } \\
\text { uncooled } \\
10^{\circ} \text { (fixed) } \\
10^{\circ} \\
\text { YES } \\
275 \mathrm{~m} / \mathrm{s} \\
<1 \mathrm{~s} \\
360 \mathrm{~m} / \mathrm{s} \\
0,3 \mathrm{~kg} \\
\text { battery life } \\
\text { propellant charge } \\
\text { analog }+/-10^{\circ} \\
2,0 \mathrm{~km} \\
\text { MLRS } \\
5000 \mathrm{sp} .
\end{gathered}
$$

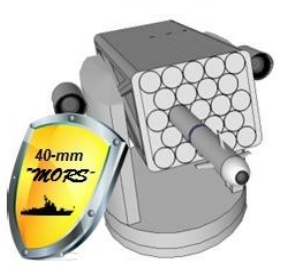

Fig. 9. Comparison of the parameters of a family of miniature missiles cal. $40 \mathrm{~mm}$ 
Paweł Dobrzyński, Stanisław Lipski, Bogdan Machowski, Rafał Miętkiewicz, Tomasz Olszewski

Tab. 3. Comparison of selected marine anti-aircraft systems with newly-developed systems self-defence and masking system of ships using miniature missile missiles cal. 70 and $40 \mathrm{~mm}$

\begin{tabular}{|c|c|c|c|c|c|c|c|c|}
\hline Name & Gibka & Sadral & $\begin{array}{c}\text { Sea } \\
\text { Stinger } 2\end{array}$ & Tetral & RIM-116A & See RAM & MORS 70 & MORS 40 \\
\hline Rocket type & $\begin{array}{l}72 \text { mm } \\
\text { Igła/Igła-S }\end{array}$ & $\begin{array}{l}90 \mathrm{~mm} \\
\text { Mistral }\end{array}$ & $\begin{array}{l}70 \mathrm{~mm} \\
\text { FIM-92 } \\
\text { Stinger }\end{array}$ & $\begin{array}{l}90 \mathrm{~mm} \\
\text { Mistral }\end{array}$ & $\begin{array}{l}127 \text { mm } \\
\text { Mk } 44\end{array}$ & $\begin{array}{l}127 \mathrm{~mm} \\
\text { Mk } 44\end{array}$ & $\begin{array}{l}70 \mathrm{~mm} \\
\text { MESKO/ } \\
\text { HYDRA }\end{array}$ & $\begin{array}{l}40 \mathrm{~mm} \\
\text { MESKO }\end{array}$ \\
\hline $\begin{array}{c}\text { Max number } \\
\text { of rockets } \\
\text { on the launcher }\end{array}$ & 12 & 6 & 4 & 4 & 21 & 11 & 4 & 23 \\
\hline $\begin{array}{l}\text { Missile length } \\
{[\mathrm{m}]}\end{array}$ & 1.69 & 1.86 & 1.52 & 1.86 & 2.82 & 2.82 & 1.47 & 0.6 \\
\hline $\begin{array}{c}\text { Rocket weight } \\
{[\mathrm{kg}]}\end{array}$ & 10.8 & 18.7 & 10.1 & 18.7 & 73.5 & 73.5 & 9.8 & 3.6 \\
\hline $\begin{array}{c}\text { Weight } \\
\text { of the launcher } \\
{[\mathrm{kg}]}\end{array}$ & 650 & 1080 & 450 & 600 & 6100 & 7750 & 300 & 100 \\
\hline $\begin{array}{c}V_{M A X} \text { rockets } \\
{[\mathrm{m} / \mathrm{s}]}\end{array}$ & 800 & 800 & 725 & 800 & 850 & 850 & 600 & 650 \\
\hline $\begin{array}{c}D_{\text {MAX }} \text { of target } \\
{[\mathrm{km}]}\end{array}$ & 5.0 & 6.0 & 4.8 & 6.0 & 6.0 & 6.0 & 6.0 & 1.5 \\
\hline $\begin{array}{c}H_{\text {MAX }} \text { of target } \\
{[\mathrm{km}]}\end{array}$ & 3.5 & 3.0 & 3.8 & 3.0 & 3.0 & 3.0 & 3.0 & 1.0 \\
\hline $\begin{array}{c}H_{M I N} \text { of target } \\
{[\mathrm{m}]}\end{array}$ & 5 & 5 & 5 & 5 & 5 & 5 & 1 & 1 \\
\hline $\begin{array}{c}\text { Speed angle } \\
{[\mathrm{rad} / \mathrm{s}]}\end{array}$ & & 1.5 & - & 1.5 & & & 1.5 & 1.5 \\
\hline $\begin{array}{l}\text { Time from } \\
\text { marching } \\
\text { position } \\
\text { to combat pos. }\end{array}$ & $<3 \min$ & & & & & & $<3 s$ & $<3 \mathrm{~s}$ \\
\hline
\end{tabular}

\section{THE POSSIBILITY OF USING 40/70 MM MLRS BY POLISH NAVY IN COMBAT OPERATIONS}

The concept of using 40/70 mm MLRS combat systems assumes that the attacking missile must approach the ship on a specific path forming a curve of curves that has the final common point (the center of gravity of the thermal radiation or reflected electromagnetic radiation depending on the way of projectile guidance used).

As the final stage of the attack takes place at low altitude, the automatic missile detection detector must constantly scan the sector in terms of vertical and horizontal angles (fig. 10). In the same way, the work of an automatic alerter takes place, after warning about the possibility of detecting the purpose, the sector automatically narrows down until it detects and starts tracking the target. Similarly, vertical scanning takes place (fig. 11). 


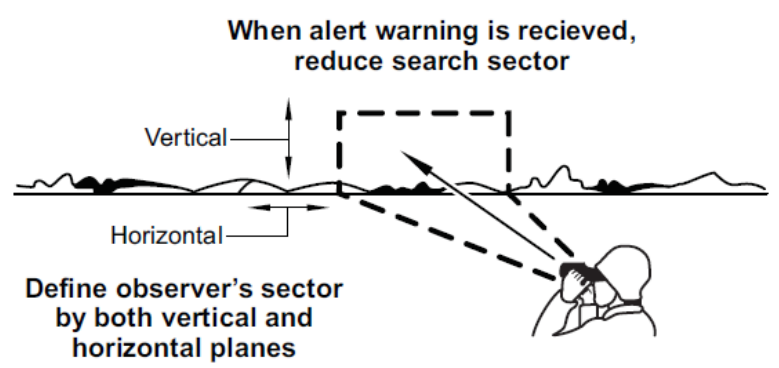

Fig. 10. The concept of sector scanning by an observer [4]

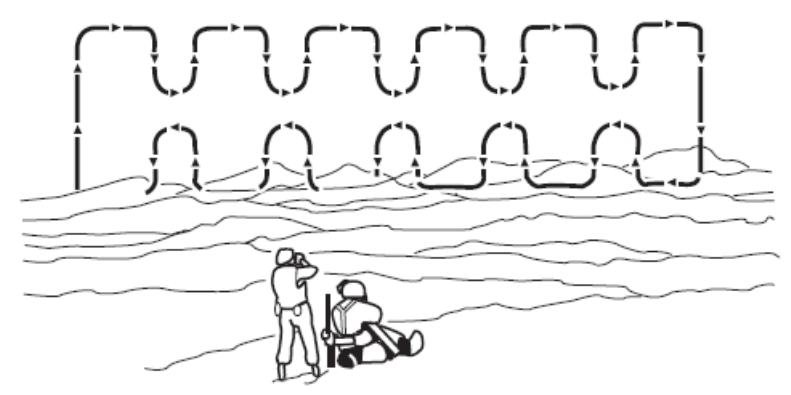

Fig. 11. The concept of scanning in the vertical plane by an observer [4]

The automated self-defence and masking module of naval vessels of the Polish Navy with the use of miniature missiles with calibre 70 and $40 \mathrm{~mm}$ must work out a decision to shoot the target like a shooter. The module is being developed as a universal, automated means of counteracting manoeuvring anti-ship missiles and all types of drones with a flight limit in the vicinity of a ship less than $1000 \mathrm{~m}$.

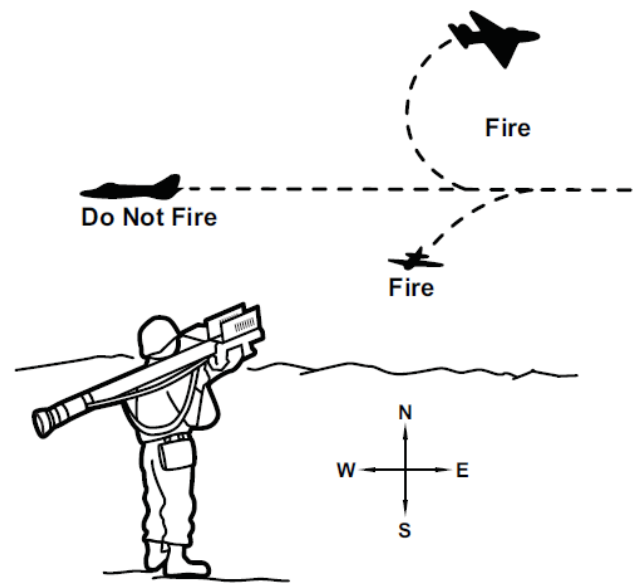

Fig. 12. Recommendations for making a decision by the MANPADS system shooter [4] 
MLRS for the $40 \mathrm{~mm}$ caliber is to influence the following (corrected/built) abilities:

1. Autonomous fire modules can work independently (working with external information about distance to the target) or cooperate with each other (exchanging data using a fiber optic), among others to passively determine the current distance to the ship's attacking object.

2. Each module has its own microprocessor system, thanks to which it works in an automatic and autonomous way - the task of the crew is only a preliminary indication of the direction of the threat and its character (based on information from other sensors).

3. The launcher has the ability to remember what type of projectile is in which tubular guide. Before firing in each projectile, the time and manner of operation of the warhead is programmed in such a way as to increase the area of the projectile or the whole salvo.

4. Rocket missiles of various types can be placed in the launcher:

- unguided - for destroying winged missiles/drones/maneuvering missiles, small boats, etc. (mass of the warhead, approx. $0.6 \mathrm{~kg}$ );

- unguided - spreading radiolocation interference in the form of foil strips (head mass approx. $0.9 \mathrm{~kg}$ );

- unguided - flares (head mass approx. $1.0 \mathrm{~kg}$ );

- unguided - smoke grenades (head weight approx. $1.3 \mathrm{~kg}$ );

- directed - self-guided infrared (mass of the warhead approx. $0.3 \mathrm{~kg}$ ).

5. It is possible to shoot simultaneously with detonating/jamming missiles.

6. Completely passive 24-hour operation in the mode: detection, tracking until the launch of a missile.

7. Ability to destroy all types of missiles that are on the approaching course.

Predicted tactical and technical parameters of the $40 \mathrm{~mm}$ module:

- composition: 2 or 4 integrated $40 \mathrm{~mm}$ missile launchers with optoelectronic sensors connected by an IT fiber optic cable (or copper twisted pair);

- the device consists of: 15-inch base with the possibility of turning its upper bed in the azimuth plane, upper bed bases containing launcher and camera drives, cameras: television and an uncooled thermal camera - which can rotate relative to the base in the elevation plane (regardless of the current location launcher in the elevation angle), cable interface, base-launcher communication, wireless IRED interface, launcher-missiles (for programming the time of activation of warhead projectile missile), electric firing system with the system of interlocks and launchers, quick-removable launcher 23-guide missiles $40 \mathrm{~mm}$ driven by the base in the elevation plane; 
- weight of the launcher without armament <= $40 \mathrm{~kg}$;

- weapons weight (23 missiles) <= $80 \mathrm{~kg}$;

- protection against unwanted movement of the launcher during the shot;

- type of base and launcher drives: self-braking worm gears driven by coupled BLDC engine pairs;

- type of camera drives: a gearless drive driven by a coupled BLDC engine pair;

- base and launcher stabilization system - based on IMU - inertial navigation unit;

- time to replace the launcher (rocket ammunition storage) $<20 \mathrm{~s}$;

- distance of launching a marching engine of $40 \mathrm{~mm}$ missiles at a minimum of $10 \mathrm{~m}$ (the projectile is ejected from the launcher by initiating the powder charge similar to a classic $40 \mathrm{~mm}$ grenade launcher);

- powered: from the on-board 18-60 AC/DC marine installation;

- without specialized training - 2 seafarers trained on an ad hoc basis;

- the missiles are mounted on the launcher (after removing it from the platform) by opening the rear gates of the launcher;

- depending on the needs, one or more missiles can be fired (maximum time of salvo < $5 \mathrm{~s}$ );

- the parameters of the flight path of the $40 \mathrm{~mm}$ caliber bullet for a limited range up to $1000 \mathrm{~m}$ are shown in fig. 13-15; collective data for changing the flight parameters of the $40 \mathrm{~mm}$ bullet for different angles of the shot are presented in tab. 4 .

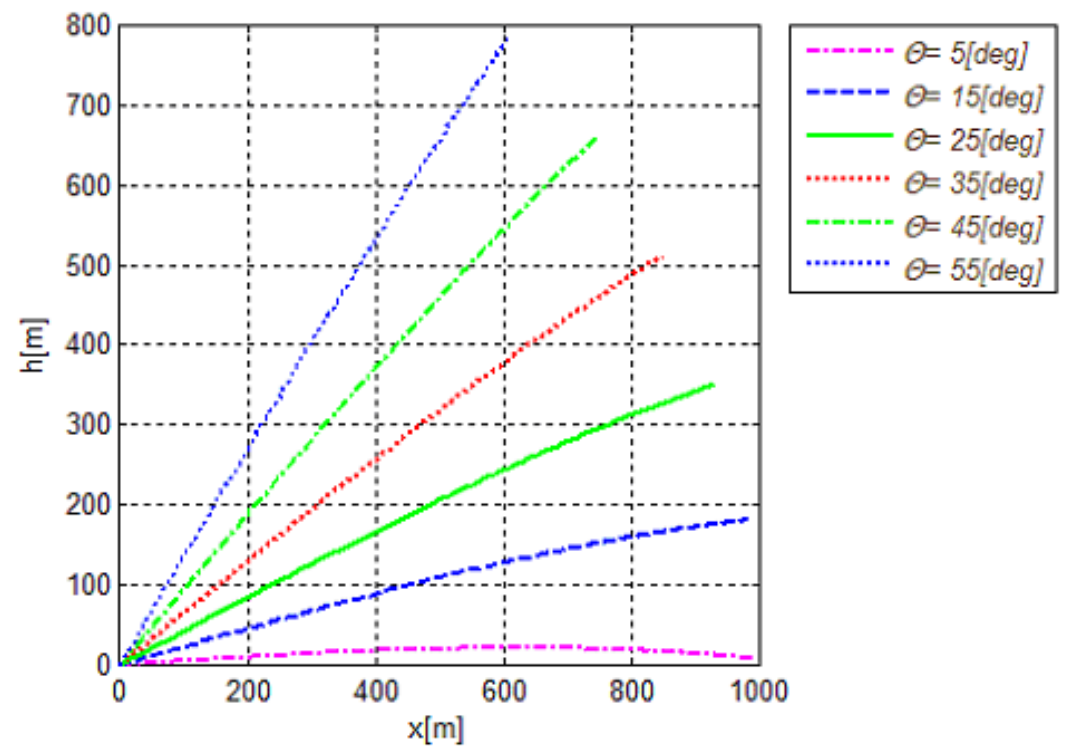

Fig. 13. Flight paths of a $40 \mathrm{~mm}$ caliber bullet for different angles of the shot 


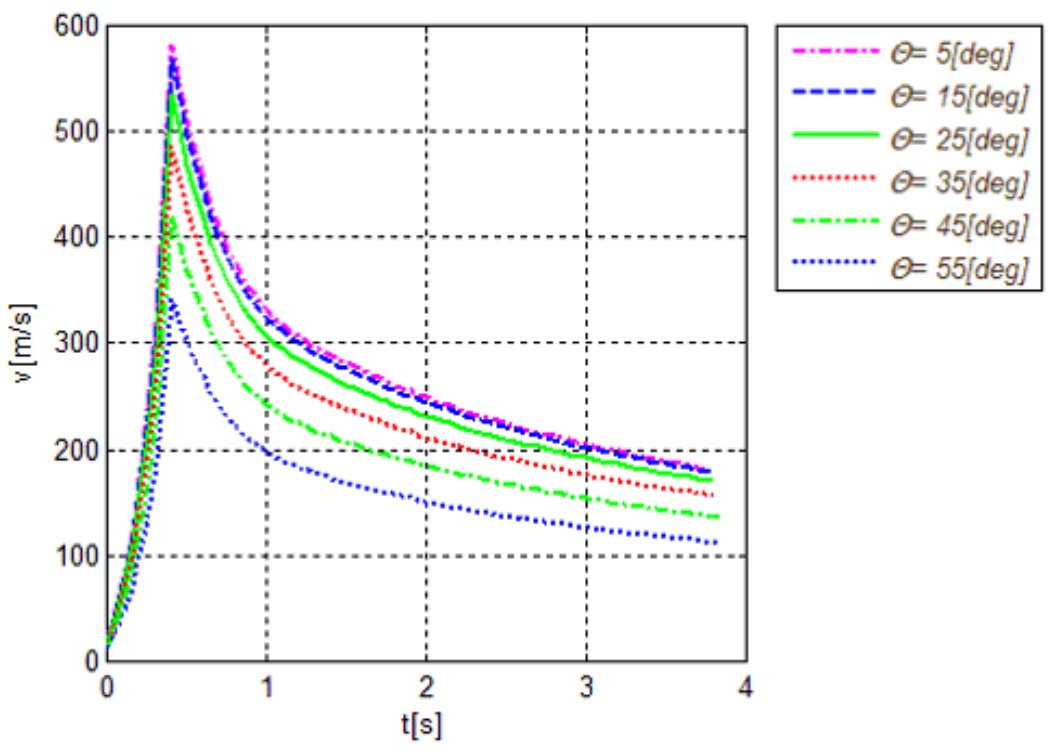

Fig. 14. Changing the speed of the $40 \mathrm{~mm}$ bullet for different angles of the shot as a function of time

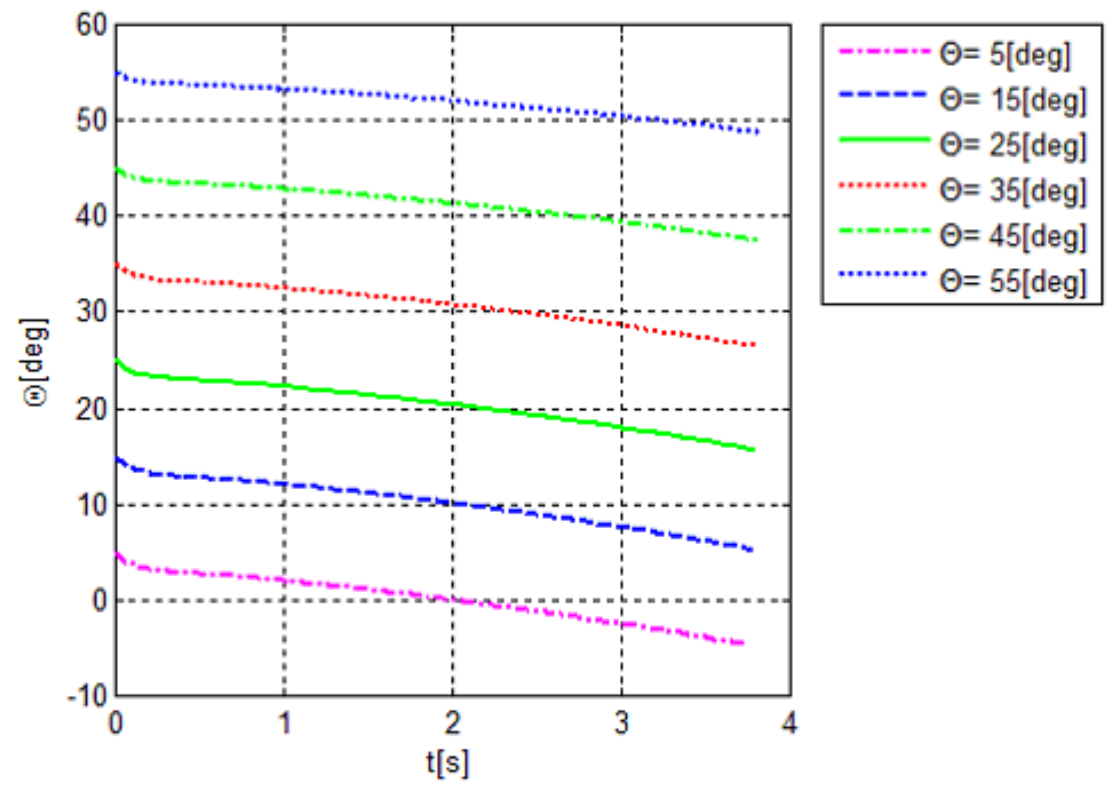

Fig. 15. Changing the angle of inclination of the velocity vector of the projectile caliber $40 \mathrm{~mm}$ for different angles of the shot as a function of time 
Tab. 4. Collective data for changing the flight parameters of a $40 \mathrm{~mm}$ caliber bullet for different angles of the shot

\begin{tabular}{|c|c|c|c|c|}
\hline $\begin{array}{c}\text { Shot angle } \\
{[\mathrm{deg}]}\end{array}$ & $\begin{array}{c}\text { Range } \\
{[\mathrm{m}]}\end{array}$ & $\begin{array}{c}\text { Max speed } \\
{[\mathrm{m} / \mathrm{s}]}\end{array}$ & $\begin{array}{c}\text { Speed } \\
\text { on average } \\
{[\mathrm{m} / \mathrm{s}]}\end{array}$ & $\begin{array}{c}\text { Time } \\
\text { of arrival } \\
{[\mathrm{s}]}\end{array}$ \\
\hline 5 & 1000 & 583 & 182 & 3.78 \\
\hline 15 & 1000 & 582 & 179 & 3.80 \\
\hline 25 & 1000 & 581 & 176 & 3.82 \\
\hline 35 & 1000 & 580 & 174 & 3.84 \\
\hline 45 & 1000 & 579 & 171 & 3.86 \\
\hline 55 & 1000 & 578 & 169 & 3.88 \\
\hline
\end{tabular}

\section{ANALYSIS OF THE POSSIBILITY OF LAUNCHING DOMESTIC PRODUCTION WITHIN THE ENTERPRISES OF POLSKA GRUPA ZBROJENIOWA S.A.}

All components necessary for the implementation of the 40 and $70 \mathrm{~mm}$ rocket weapon system are available nationally and can be produced or adapted by enterprises belonging to Polska Grupa Zbrojeniowa S.A. Predicted tactical and technical parameters of polonized rockets 2.75":

- uniform launcher module for guided and non-guided missiles;

- interchangeability with missiles used in aviation, helicopter, sea and land systems;

- take-off weight of an unguided missile < $10 \mathrm{~kg}$;

- length $\max =1500 \mathrm{~mm}(70 \mathrm{~mm}) / 800 \mathrm{~mm}(40 \mathrm{~mm})$;

- weight of the warhead up to $3 \mathrm{~kg}$;

- range of unguided missiles up to $10 \mathrm{~km}$;

- range of missiles directed up to $3 \mathrm{~km}$.

In order to implement the $40 \mathrm{~mm}$ missile project, on December 28, 2017, a scientific and industrial consortium was formed in which the Leader - Military University of Technology (Faculty of Mechatronics and Aviation), Polska Grupa Zbrojeniowa S.A., MESKO S.A. and Warsaw University of Technology. The Polish Center for Optoelectronics (PCO S.A.) submitted its accession to the consortium in March 2018. An illustration of entities interested in the development of $40 \mathrm{~mm}$ bullets 'Pocket Rocket Artillery' is shown in fig. 16.

The purpose of the presented project is the practical implementation of the prototype of the 'Automated system of self-defence and masking of Navy ships 
with the use of miniature $40 \mathrm{~mm}$ rocket missiles', which could be used as a universal, automated means of counteracting maneuvering anti-ship missiles and all types of drones with a smaller ship's surrounding than $1000 \mathrm{~m}$.

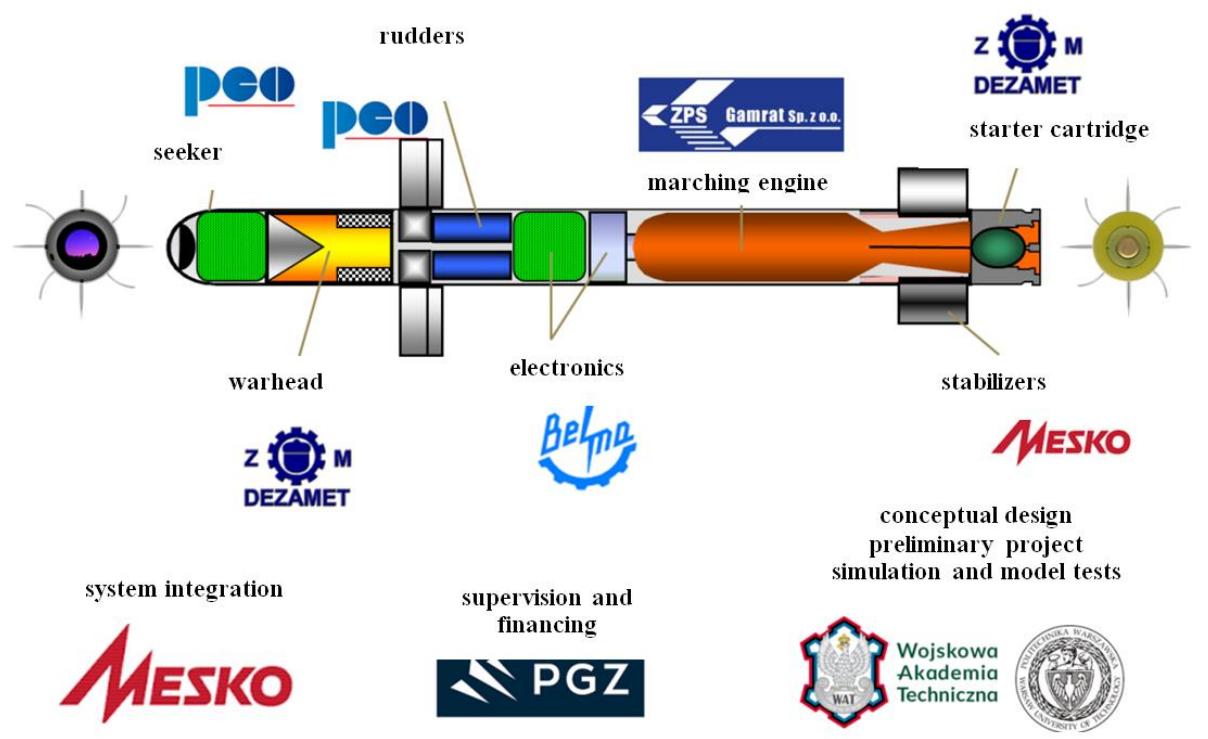

Fig. 16. Illustration of the division of tasks of entities interested in development 'Pocket Rocket Artillery'

\section{CONCLUSIONS}

Analyses and results obtained from simulation tests indicate that the automated missile self-defence system based on guided and unguided missiles with caliber of $40 \mathrm{~mm}$ and $70 \mathrm{~mm}$ can be an effective means of self-defence, even the smallest vessels of the Republic of Poland. The correctness of the adopted constructional solutions as well as the functional and operational functionality were confirmed, and the characteristics and parameters achieved by the system qualify him positively to undertake work on this project, in order to implement and introduce for Polish Navy.

The introduction of an automated missile self-defence system based on guided and unguided missiles with caliber of $40 \mathrm{~mm}$ and $70 \mathrm{~mm}$ for troops is another step in modernizing the Polish army, based on the national defence industry. Its implementation will require the necessary active involvement of entities specializing in marine systems such as the Naval Academy or Center for Marine Technology S.A. 
Thanks to the implementation of MLRS with 'MORS' missiles, there would be a significant increase in the safety of Navy (or civilian) ships,which may be threatened by attacks of maneuvering missiles and drones moving is of low altitude at high speed. Navy ships as well as future autonomous systems will significantly increase their operational capabilities in terms of increasing the probability of effective defence and more effective counteracting threats.

\section{REFERENCES}

[1] Dobrzyński P., Lipski S., Machowski B., Głowica kumulacyjno-odłamkowa przeciw śmigłowcom i pojazdom opancerzonym, [in:] Wyzwania i rozwój obrony powietrznej Rzeczypospolitej Polskiej - obronność RP XXI wieku, Publ. Akademia Sztuki Wojennej (in print) [Cumulative and fragmentation head against helicopters and armored vehicles, in: Challenges and development of the air defense of the Republic of Poland - defense of the 21st century Poland - available in Polish].

[2] Dobrzyński P., Lipski S., Machowski B., Olszewski T., Koncepcja polonizacji pocisków rakietowych kalibru 2,75", XXI Międzynarodowa Szkoła Komputerowego Wspomagania Projektowania, Wytwarzania i Eksploatacji [XXI International School of Computer Aided Design, Production and Exploitation], Jurata 2017, pp. 119-133 [Polonization concept for 2.75 caliber missiles available in Polish].

[3] Fleeman E., Tactical Missile Design, AIAA Education Series, 2nd edition, August 4, 2006.

[4] Low Altitude Air Defence (LAAD), Gunner,s Handbook, US Marine Corps, May 9, 2011.

[5] Tactical and Strategic Missile Guidance (Progress in Astronautics and Aeronautics), AIAA, 6th edition, September 18, 2013.

\section{ZAUTOMATYZOWANY MODUE SAMOOBRONY I MASKOWANIA OKRĘTÓW MARYNARKI WOJENNEJ RP Z WYKORZYSTANIEM MINIATUROWYCH POCISKÓW RAKIETOWYCH KAL. 40 I 70 MM}

\section{STRESZCZENIE}

Artykuł jest próbą zainteresowania podmiotów związanych z techniką morską możliwościami zwiększenia bezpieczeństwa okrętów marynarki wojennej (lub statków cywilnych), które mogą być zagrożone atakami pocisków manewrujących i dronów przemieszczających się 
na małej wysokości z dużą prędkością. Zaproponowana przez zespół autorski koncepcja została wstępnie zweryfikowana w badaniach symulacyjnych, a otrzymane wyniki wskazują, że zautomatyzowany system samoobrony rakietowej w oparciu o kierowane i niekierowane pociski rakietowe kal. $40 \mathrm{~mm}$ i $70 \mathrm{~mm}$ może być skutecznym środkiem samoobrony nawet najmniejszych jednostek pływających. Małe gabaryty i masa oraz prostota użycia i niezawodność tego systemu broni pozwalają sądzić, że $40 \mathrm{~mm}$ MLRS mogłyby stanowić uzbrojenie lekkich bezzałogowców i być wykorzystywane przez wojska specjalne marynarki wojennej w operacjach zaczepnych (niszczenie lekko opancerzonych obiektów nawodnych lub naziemnych, pojazdów, siły żywej, stawianie zasłon dymnych, minowanie terenu w odległości do $2000 \mathrm{~m}$ itp.). Z tej przyczyny system ten określany jest przez zespół realizatorów jako „kieszonkowa artyleria rakietowa”.

\section{Słowa kluczowe:}

morskie systemy walki, bezpieczeństwo i ochrona żeglugi, uzbrojenie i sprzęt specjalistyczny, ochrona portów i infrastruktury krytycznej, uzbrojenie i sprzęt specjalistyczny, rakietowe systemy samoobrony i maskowania okrętów, badania i certyfikacja wyrobów w zakresie obronności i bezpieczeństwa RP.

Article history

Received: 22.05.2018

Reviewed: 12.07 .2018

Revised: $\quad 28.09 .2018$

Accepted: 29.09 .2018 